\title{
CONTROVERSIES
}

\section{IVF mixup: white couple have black babies}

\section{Spriggs}

A n IVF mixup has resulted in a white couple giving birth to black twins. Prior to DNA testing, no one can be sure whether the white woman's eggs were fertilised with the black man's sperm, or the black couple's embryo was mistakenly implanted in the white woman. It is believed that $\mathrm{Mr}$ and Mrs A, the white couple, want to keep the babies and there is conjecture about Mr and Mrs B, the black couple, wanting them too. ${ }^{1}$ Under the Human Fertilisation and Embryology Act 1990, a woman who has a child born through IVF, even if it is not genetically hers, is the "legal mother". Paternity, however, is "open to legal interpretation". ${ }^{1-3}$

News of the mixup has elicited a range of reactions. It is thought that this case will cause huge concern among the many thousands of couples who have used IVF because mistakes could be going unnoticed. Mistakes are only apparent when a couple has a child of a different colour. In vitro fertilisation clinics are being urged to review and tighten procedures and Melbourne IVF experts have announced that they have developed a test to check the paternity of embryos and prevent "blunders" like the one that has occurred in Britain. The genetic test will be available soon and couples will pay around $\mathrm{A} \$ 2000$ for it. ${ }^{14}$

In vitro fertilisation mixups have occurred before but not in Britain. In the US in 1998, a white woman gave birth to one white and one black baby in what became known as the "scrambled eggs" case. After a "bitter custody battle" the black couple whose embryo was mistakenly implanted into the white woman won custody of the black baby. In the Netherlands in 1993, a white woman gave birth to one black and one white child after receiving "mixed sperm from a poorly sterilised pipette". The biological father of that child did not try to claim his black biological child. ${ }^{5}$

The hysterical response generated by the British mixup was examined in one newspaper. A British woman who has IVF twins who were born white writes:

So how can I guarantee that they really are part of my family? Because I gave birth to them, fed them, and I am rearing them to the best of my ability. There is nothing that can make them more our children. If I discovered that, in fact, they were the result of a stranger's egg being accidentally lodged in the pipette that reimplanted my own, it would, of course, cause some heartache. But it would not-could not-make them less mine. ${ }^{3}$

It is ironic, she concludes, in relation to the mixup with the black IVF babies, if both couples want the babies; it "only goes to prove that their genetic makeup and colour is not of prime importance to either couple". ${ }^{3}$
Several weeks after news of the mixup, genetic testing revealed that Mrs A is the babies' "biological mother" but her husband, Mr A, is not their "biological father". ${ }^{6}$ The legal parentage and the fate of the twins is to be decided by the High Court. ${ }^{7}$ An independent inquiry into the mixup has also been launched. ${ }^{8}$

It was revealed in October 2002 that another IVF mixup had occurred in Britain. In April, two women were given the "wrong embryos" in a mixup involving three women. One woman was implanted with her own "poorer quality embryos" while her "best quality pair" went to another woman whose embryos were given in error to a third woman. The women who got the "wrong embryos" have been left "devastated" and "traumatised" after undergoing an "emergency procedure to have the embryos removed". ${ }^{10}$

\section{AUTHOR'S NOTE}

The High Court has named the biological father ( $\mathrm{Mr} \mathrm{B})$ as the legal father of the black twins but ruled that the twins are to stay with the white couple ( $\mathrm{Mr}$ and Mrs A). ${ }^{11}$

\section{Author's affiliatic \\ M Spriggs, Royal Childrens Hospital, Victoria, Australia}

Correspondence to: Dr M Spriggs, Ethics Unit, Murdoch Childrens Research Institute, Royal Childrens Hospital, Flemington Road, Parkville, Victoria, 3052, Australia; spriggsm@murdoch.rch.unimelb.edu.au

Accepted for publication 2 December 2002

\section{REFERENCES}

1 Morris S. Clinics urged to tighten checks after embryo mixup. The Guardian 2002 Jul 10. See www.guardian.co.uk (accessed 15 July 2002) and follow the links for the index.

2 Dyer C. Couple in IVF mixup wait for court date. The Guardian 2002 July 10. See society.guardian.co.uk (accessed 15 July 2002) and follow the links for the index.

3 Birkett D. IVF errors and questions of race. The Guardian 2002 July 10. See www.guardian.co.uk (accessed 15 July 2002) and follow the links for the index.

4 Hargreaves W. Test to prevent IVF race mixup. Herald Sun 2002 July 10: news section: 4

5 Dyer 0 . Black twins are born to white parents after infertility treatment. BM 2002;325:64

6 Anon. Inquiry into IVF twins blunder. BBC News (health section) 2002 July 17. See news.bbc.co.uk (accessed 18 July 2002) and follow the inks for the index.

7 Dyer C. Black father identified in IVF mixup. The Guardian 2002 Aug 1 See www.guardian.co.uk (accessed 5 August 2002) and follow the links for the index.

8 Anon. Inquiry into IVF twins blunder. BBC News (health section): 2002 July 17. See news.bbc.co.uk (accessed 6 December 2002) and follow the links for the index.

9 Anon. Embryo mixup at IVF hospital. BBC News (health section) 2002 Oct 28. See news.bbc.co.uk (accessed 6 December 2002) and follow the links for the index.

10 Allen R. IVF mixup at London clinic. The Evening Standard 2002 Oct 28. See www.thisislondon.co.uk (accessed 6 December 2002) and follow the links for the index.

11 Anon. Court rules on father of IVF mix-up twins. BBC News (health section) 2003 Feb 26. See news.bbc.co.uk (accessed 27 February) and follow the links for the index. 